\title{
Kinerja Mesin Pellet dalam Produksi Pakan Ayam Pedaging Fase Finisher
}

\author{
Ichlasul Amal, Jamila, Jasmal A. Syamsu \\ Laboratorium Teknologi dan Industri Pakan, Fakultas Peternakan Universitas Hasanuddin \\ Jalan Perintis Kemerdekaan Km.10 Kampus UNHAS Tamalanrea, Makassar \\ *Email korespondensi: ilallambrosso728@gmail.com
}

(Diterima 13-08-2020; disetujui 14-09-2020)

\begin{abstract}
ABSTRAK
Penelitian ini bertujuan untuk mengetahui kapasitas kinerja mesin dalam produksi pakan pellet ayam pedaging fase finisher dengan berbagai bahan perekat. Penelitian disusun menggunakan Rancangan Acak Lengkap (RAL) terdiri dari 4 perlakuan dengan 4 ulangan. Perlakuan penambahan bahan perekat yaitu $\mathrm{P} 0=$ tanpa menggunakan bahan perekat, $\mathrm{P} 1=$ penambahan molases $2 \%, \mathrm{P} 2=$ penambahan tepung tapioka $2 \%, \mathrm{P} 3$ $=$ penambahan bentonit $2 \%$. Parameter yang diukur dalam penelitian adalah kinerja teoritis dan kinerja aktual mesin pellet, ukuran diameter dan panjang pellet, serta kualitas organoleptik pellet. Hasil penelitian menunjukkan penambahan berbagai bahan perekat tidak berpengaruh nyata $(\mathrm{P}>0.05)$ terhadap kinerja teoritis mesin pellet, kinerja aktual mesin pellet, serta ukuran diameter dan panjang pellet. Berdasarkan uji organoleptik pellet dengan kriteria tekstur, warna, serta bau menunjukkan bahwa lebih $50 \%$ panelis memberi penilaian kategori baik pada kriteria tersebut pada pellet yang diberi bahan perekat. namun, perlakuan tanpa bahan perekat sebanyak 41,67\% panelis menyatakan teskstur pellet dengan kategori jelek. Disimpulkan bahwa dengan penambahan berbagai bahan perekat tidak berpengaruh terhadap kinerja mesin pellet, dan ukuran partikel pellet, untuk uji organoleptik menunjukkan lebih 50\% panelis menyatakan kategori baik pada kriteria tekstur, warna serta bau, sedangkan tanpa bahan perekat persentase tertinggi panelis menyatakan teskstur pellet dengan kategori jelek.
\end{abstract}

Kata kunci: bahan perekat, kinerja mesin, kualitas fisik, organoleptik pellet

\begin{abstract}
This research aims to determine performance capacity of the machine in production of finisher phase broiler pellet feed with various binders. The research used a completely randomized design (CRD) consist of 4 treatments with 4 replications. The treatment of adding binders are $\mathrm{P} 0=$ without using binders, $\mathrm{P} 1=$ addition $2 \%$ molasses, $\mathrm{P} 2=$ addition $2 \%$ tapioca flour, $\mathrm{P} 3=$ addition $2 \%$ bentonite. The parameters measured in the research were the theoretical performance and actual performance of the pellet machine, the diameter and length of the pellet, as well as the organoloptic quality of pellet. The results showed the addition of a variety of binders no significant effect $(\mathrm{P}>0.05)$ against the theoretical performance of pellet machines, the actual performance of pellet machines, as well as the size of diameter and length of pellets. Based on organoleptic test pellets with texture, color, and smell criteria showed that more than $50 \%$ of panelists gave a category rating on the criteria on pellets that were given binders. On the other hand, treatment without adhesives as much as $41,67 \%$ of panelists stated that the texture of pellets was in the bad category. It can be concluded that the addition of various binders has no effect on the performance of the machine, and the size of the pellet particles. For the organoleptic test, it showed that more than $50 \%$ of panelists stated good categories in the criteria of texture, color and smell, while without adhesive, the highest percentage of panelists stated that the pellet texture was in the bad category.
\end{abstract}

Keywords: binder, machine performance, physical quality, organoleptic pellet

\section{PENDAHULUAN}

Dewasa ini suatu perusahaan atau industri yang menghasilkan suatu produk sebaiknya memiliki strategi yang baik dalam pemenuhan permintaan konsumen. Persaingan yang sangat kompetitif antar perusahaan atau industri manufaktur mengharuskan pihak manajemen produksi perusahaan merencanakan kapasitas produksinya dengan tepat agar dapat memenuhi 
permintaan konsumen dengan baik. Karena bukan tidak mungkin, dengan tidak adanya perencanaan kapasitas produksi pada suatu industri akan membuat proses produksi menjadi tidak terkendali. Dalam dunia industri manufaktur konsumen merupakan faktor penting dalam terget penjualan produk untuk meningkatkan keuntungan perusahaan di masa mendatang (Nugraha, 2017).

Proses pengolahan ransum di pabrik pakan merupakan proses produksi dengan menggunakan mesin-mesin pemrosesan yang menghasilkan ransum dalam bentuk mash, pellet dan crumble (Krisnan dan Ginting, 2009). Penggunaan bentuk pakan tersebut harus sesuai terhadap fase ternak yang dipelihara. Khusus untuk fase finisher pada ternak ayam pedaging, pakan yang banyak digunakan dalam bentuk pellet. Kejadian yang masih banyak dijumpai pada pakan berbentuk pellet di lapangan adalah tekstur cepat rusak, pecah maupun patah selama produksi, pengangkutan dan penyimpanan. Salah satu yang mempengaruhi kondisi tersebut adalah bahan perekat (Retnani et al., 2009; Syamsu, 2007).

Binder sebagai bahan perekat bahan baku pakan dibedakan menjadi dua jenis yaitu bahan perekat alami dan bahan perekat buatan. Bahan perekat alami telah banyak digunakan sebagai bahan perekat untuk berbagai pakan, antara lain tepung tapioka, tepung gaplek, molases, serta rumput laut. (Sari et al., 2016). Perekat merupakan suatu bahan yang mempunyai fungsi mengikat komponen-komponen pakan dalam bentuk pellet sehingga strukturnya tetap kompak. Penambahan perekat lignosulfonat dan bentonit dan proses pengolahan diduga dapat meningkatkan sifat fisik ransum ayam broiler bentuk pellet. Pabrik pakan biasanya menggunakan bahan perekat sintetis, seperti lignosulfonat dan bentonit (Retnani et al., 2010). Namun, perekat sintetis relatif mahal, sehingga perlu adanya perekat alternatif dari bahan pakan seperti tepung tapioka atau molases.

Tepung tapioka merupakan salah satu jenis perekat yang dapat digunakan dalam pembuatan pelet. Menurut Adi et al., (2013) berdasarkan hasil analisis proksimat, tepung tapioka memiliki kandungan lemak, protein dan karbohidrat sebesar 85-88\%, hasil analisis ini sudah melebihi standar SNI tapioka yaitu lebih dari $70 \%$. Selain kandungan karbohidrat yang tinggi, tepung tapioka juga berfungsi sebagai perekat pakan (binder). Tepung tapioka memiliki amilosa dan amilopektin sebesar $17 \%$ dan $83 \%$. Molases merupakan hasil samping pada industri pengolahan gula dengan bentuk cair. Kandungan yang terdapat pada molases antara lain $20 \%$ air, $3,5 \%$ protein, $58 \%$ karbohidrat, $0,80 \% \mathrm{Ca}$,
0,10\% pospor dan $10,50 \%$ bahan mineral lain (Pujaningsih, 2006).

Pentingnya sifat fisik pakan untuk diketahui karena berkaitan dengan proses pengolahan, penanganan, penyimpanan dan perancangan alatalat yang dapat membantu proses produksi pakan, membantu industri pengolahan hasil pertanian serta berperan dalam menerapkan teknologi pengolahan lanjutan agar dapat digunakan secara optimal (Yatno, 2011). Sifat bahan serta perubahan yang terjadi pada pakan dapat digunakan untuk menilai dan menetapkan mutu pakan, disamping itu pengetahuan tentang sifat fisik dapat digunakan juga untuk menentukan keefisienan suatu proses penanganan, pengolahan, dan penyimpanan.

Kinerja suatu mesin dapat ditinjau dari kemampuan produksi dan menghasilkan suatu produk yang berkualitas untuk memenuhi kebutuhan konsumen, dengan demikian, perlu diketahui kemampuan produksi pada kinerja mesin pellet yang digunakan dan pengaruh bahan perekat tepung tapioka dan molases menggantikan bahan perekat sintetis terhadap sifat pellet pakan ayam pedaging fase finisher. Penelitian ini bertujuan untuk mengetahui kapasitas kinerja mesin dalam produksi pakan pellet ayam pedaging fase finisher dengan berbagai bahan perekat.

\section{MATERI DAN METODE}

Penelitian ini dilaksanakan pada bulan Juni sampai dengan Juli 2020 di Laboratorium Teknologi dan Industri Pakan Fakultas Peternakan, Universitas Hasanuddin, Makassar. Bahan yang digunakan dalam penelitian ini adalah konsentrat ayam pedaging fase finisher berbentuk mash PT. Charoend Pokphand Indonesia, jagung, dedak, bentonit, tepung tapioka, molases, air dan plastik.

Penelitian ini menggunakan Rancangan Acak Lengkap (RAL) (Steel and Torrie, 1991) terdiri dari 4 perlakuan dan 4 ulangan sehingga diperoleh 16 unit percobaan. Susunan perlakuan sebagai berikut:

P0 : Ransum ayam pedaging fase finisher tanpa menggunakan bahan perekat

P1 : Ransum ayam pedaging fase finisher + molases $2 \%$

P2 : Ransum ayam pedaging fase finisher + tepung tapioka $2 \%$

P3 : Ransum ayam pedaging fase finisher + bentonit 2\%

Pelaksanaan penelitian dilakukan dengan tahapan-tahapan yaitu penyiapan ransum, formulasi ransum dan pencampuran bahan pakan, penambahan bahan perekat, penambahan air, proses 
pencetakan pellet, pendinginan dan pengeringan, pengambilan sampel, pengukuran parameter penelitian.

Ransum dalam penelitian ini disusun menggunakan konsentrat ayam pedaging fase finisher dalam bentuk mash (SBC 12) yang diproduksi oleh PT. Charoend Pokphand Indonesia, jagung yang diperoleh dari CV. Barbas Agro Celebes serta dedak padi yang diperoleh dari penggilingan padi di Kabupaten Sidrap. Kualitas bahan ransum yang digunakan seperti terlihat pada Tabel 1.

Ransum ayam pedaging fase finisher disusun berdasarkan standar kebutuhan ayam pedaging fase finisher sesuai dengan SNI 8173.3:2015 (Tabel 2). Formulasi ransum dengan menggunakan bahan konsentrat ayam pedaging fase finisher, jagung serta dedak padi dengan susunan formulasi ransum seperti terlihat pada Tabel 3. Pencampuran pakan berdasarkan formulasi ransum pada Tabel 3 sebanyak $80 \mathrm{~kg}$ bahan dicampur menggunakan mesin horizontal mixer dengan waktu pencampuran selama 30 menit. Ransum yang sudah homogen di masukkan ke dalam empat karung masing-masing $20 \mathrm{~kg}$ sesuai dengan jumlah perlakuan.

Penambahan bahan perekat dilakukan dengan cara mencampur ransum dengan bahan perekat sesuai dengan perlakuan. Bahan perekat dicampur secara manual di atas terpal dengan metode quartering yaitu disebar menjadi segiempat kemudian seperempat bagian dicampur dengan bahan perekat setelah itu disatukan kembali dengan bagian yang lain hingga homogen.

Proses penambahan air dilakukan dengan cara menyemprotkan air menggunakan pressure sprayer ke setiap ransum yang telah ditambahkan bahan perekat. Penambahan kadar air berdasarkan kondisi kadar air awal bahan hingga mencapai pada taraf 30-35\% diukur dengan menggunakan alat grain moisture meter. Proses pencetakan pellet menggunakan mesin pellet jenis Farm Feed Pelleter dengan tenaga penggerak mesin Kubota dengan putaran pully $1000 \mathrm{rpm}$.

Tabel 1. Analisis kandungan nutrisi bahan penyusun ransum yang digunakan dalam pembuatan pellet

\begin{tabular}{lccccc}
\hline \multicolumn{1}{c}{ Bahan } & $\begin{array}{c}\text { Kadar Air } \\
(\%)\end{array}$ & $\begin{array}{c}\text { Protein } \\
\text { Kasar }(\%)\end{array}$ & $\begin{array}{c}\text { Serat Kasar } \\
(\%)\end{array}$ & $\begin{array}{c}\text { Lemak Kasar } \\
(\%)\end{array}$ & Abu (\%) \\
\hline $\begin{array}{l}\text { 1. } \\
\text { Konsentrat ayam pedaging } \\
\text { fase finisher }\end{array}$ & 10,32 & 37,66 & 6,04 & 4,14 & 17,42 \\
& 10,72 & 8,78 & 3,31 & 5,35 & 1,85 \\
2. Jagung & 10,79 & 7,34 & 8,23 & 10,60 & 6,47 \\
\hline 3. & Dedak padi & &
\end{tabular}

Sumber: Hasil Analisis Laboratorium Bioteknologi Terpadu Fakultas Peternakan Universitas Hasanuddin (2020)

Tabel 2. Kebutuhan ayam pedaging finisher

\begin{tabular}{|c|c|}
\hline Parameter & Persyaratan (\%) \\
\hline Kadar Air (Maks.) & 14 \\
\hline Protein Kasar (Min.) & 19 \\
\hline Serat Kasar (Maks.) & 6 \\
\hline Lemak Kasar (Min.) & 5 \\
\hline Abu (Maks.) & 8 \\
\hline
\end{tabular}

Sumber: (SNI 8173.3:2015)

Tabel 3. Komposisi ransum ayam pedaging fase finisher penelitian

\begin{tabular}{lcc}
\hline \multicolumn{1}{c}{ Bahan } & Komposisi (\%) & Bahan (kg) \\
\hline Konsentrat ayam pedaging fase Finisher & 50 & 40 \\
Jagung & 35 & 28 \\
Dedak padi & 15 & 12 \\
\hline Jumlah & 100 & 80 \\
\hline
\end{tabular}


Bahan dimasukkan ke dalam pelleting chamber melalui corong. Dalam pelleting chamber terjadi proses mekanik antara roller dan die, di mana roller akan menekan bahan ke dalam die sebagai tempat mencetak dan keluarnya pellet. Kemudian dilakukan pengukuran suhu mesin pada tempratur $60-70^{\circ} \mathrm{C}$, diukur pada saat proses pencetakan pellet dengan menggunakan alat infrared thermometer. Bagian bawah die, terdapat pisau untuk memotong pellet dan mengatur ukuran panjang yang keluar dari lubang die. Pellet yang keluar ditampung dalam wadah.

Pellet yang telah diproduksi dilakukan proses pendinginan untuk menurunkan suhu dengan menggunakan aliran udara dalam suhu ruangan. Selanjutnya, dilakukan proses pengeringan dengan bantuan cahaya matahari hingga kadar air pellet pada taraf kadar air 10-12\%. Retnani (2015), menyatakan pengeringan ini bertujuan untuk menurunkan kadar air yang terkandung di dalam pakan atau pellet, sehingga menjadi minimal dan stabil (sekitar 10\%). Dengan demikian, pakan yang telah dibuat tidak mudah ditumbuhi jamur atau mikroba. Pengeringan dapat dilakukan secara alami dengan bantuan sinar matahari.

Pengambilan sampel menggunakan metode quartering berdasarkan SNI 13-6717-2002 tentang tata cara penyiapan benda uji dari contoh agregat. Metode quartering adalah metode percontohan dengan mengambil bahan yang akan diambil sampelnya lalu disebar menjadi segiempat atau lingkaran kemudian di bagi menjadi empat bagian lalu diambil $1 / 4$ bagian. Dimana dari $1 / 4$ bagian tersebut sudah mewakili keseluruhan. Pengambilan sampel sebanyak 2,5 kg setiap perlakuan dilakukan untuk uji fisik dan perhitungan kinerja mesin pellet.

Parameter yang diamati dalam penelitian ini adalah kapasitas kinerja teoritis, kapasitas kinerja aktual, efisiensi kinerja mesin pellet (Purwantoro et al., 2018), ukuran partikel pellet ayam pedaging fase finisher, serta uji organoleptik pakan pellet ayam pedaging fase finisher dengan 15 orang panelis yang sebelumnya telah diberikan pemahaman (Sulistiyanto et al., 2016).

\section{HASIL DAN PEMBAHASAN}

\section{Kapasitas Kinerja Mesin Pellet Ayam Pedaging Fase Finisher}

Kapasitas kinerja teoritis, kapasitas kinerja aktual, serta efisiensi kinerja mesin dengan penambahan berbagai bahan perekat dapat dilihat pada Tabel 4. Berdasarkan hasil penelitian diperoleh kapasitas kinerja mesin pada masing-masing pelakuan $\mathrm{P} 0, \mathrm{P} 1, \mathrm{P} 2$, serta $\mathrm{P} 3$ untuk kinerja teoritis adalah $32,27 \mathrm{~kg} / \mathrm{jam}, 32,71 \mathrm{~kg} / \mathrm{jam}, 33,33 \mathrm{~kg} / \mathrm{jam}$, serta $36,15 \mathrm{~kg} / \mathrm{jam}$, dan kinerja aktual $27,55 \mathrm{~kg} / \mathrm{jam}$, $29,42 \mathrm{~kg} / \mathrm{jam}, 28,95 \mathrm{~kg} / \mathrm{jam}, 32,23 \mathrm{~kg} / \mathrm{jam}$.

Berdasakan kapasitas kinerja teoritis dan kinerja aktual maka diketahui efisiensi kinerja (EK) mesin pada setiap perlakuan yaitu lebih dari $80 \%$. Hal ini menunjukkan efisiensi kinerja mesin tinggi, sesuai dengan pendapat Smith dan Wilkes (1990) yaitu jika EK $\geq 80 \%$, artinya efisiensi penggunaan mesin tinggi. Jika EK < 80\%, artinya efisiensi pengggunaan mesin rendah. Kapasitas efisiensi kinerja dapat dipengaruhi oleh keadaan fisik dan kualitas dari alat tersebut, selain dipengaruhi oleh alat itu sendiri juga dapat dipengaruhi oleh keterampilan operator.

Berdasarkan analisis ragam menunjukkan bahwa penambahan berbagai bahan perekat tidak berpengaruh nyata $(\mathrm{P}>0.05)$ terhadap kapasitas kinerja teoritis mesin pellet dan kinerja aktual mesin pellet. Hal ini disebabkan karena penambahan berbagai bahan perekat yang digunakan tidak memiliki pengaruh terhadap kinerja mesin pellet. Namun, pada berat bahan pellet dengan berat hasil pellet terdapat penyusutan sehingga mempengaruhi hasil perhitungan kapasitas kinerja teoritis dengan kapasitas kinerja aktual (Tabel 4).

Tabel 4. Kapasitas kinerja teoritis, kapasitas kinerja aktual, serta efisiensi kinerja mesin dalam dalam proses pemeletan pakan ayam pedaging fase finisher

\begin{tabular}{cccc}
\hline \multirow{2}{*}{ Perlakuan } & \multicolumn{3}{c}{ Parameter } \\
\cline { 2 - 4 } & $\begin{array}{c}\text { Kapasitas Kinerja Teoritis } \\
(\mathrm{kg} / \mathrm{jam})\end{array}$ & $\begin{array}{c}\text { Kapasitas Kinerja Aktual } \\
(\mathrm{kg} / \mathrm{jam})\end{array}$ & $\begin{array}{c}\text { Efisiensi Kinerja Mesin } \\
(\%)\end{array}$ \\
\hline P0 & $32,27 \pm 7,38$ & $27,55 \pm 6,06$ & $86 \pm 1,00$ \\
P1 & $32,71 \pm 3,10$ & $29,42 \pm 2,77$ & $90 \pm 4,32$ \\
P2 & $33,33 \pm 5,30$ & $28,95 \pm 4,23$ & $87 \pm 1,15$ \\
P3 & $36,15 \pm 7,12$ & $32,23 \pm 6,72$ & $89 \pm 1,15$ \\
\hline
\end{tabular}




\section{Pengamatan Organoleptik Pellet Ayam Pedaging Fase Finisher}

Hasil pengamatan organoleptik oleh panelis pellet ayam pedaging fase finisher dengan penambahan berbagai bahan perekat dapat dilihat pada Tabel 5. Berdasarkan uji organoleptik pellet ayam pedaging fase finisher dengan kriteria tekstur, warna, serta bau menunjukkan bahwa lebih dari 50\% panelis memberi penilaian kategori baik pada pellet yang diberi bahan perekat (P1, P2, P3). Penambahan berbagai bahan perekat pada pellet ayam pedaging fase finisher memiliki kualitas fisik dengan kriteria tekstur, warna serta bau yang baik sehingga penilaian panelis lebih tinggi pada perlakuan menggunakan bahan perekat dibandingkan dengan tanpa menggunakan bahan perekat.

Perlakuan P0 tanpa bahan perekat sebanyak $41,67 \%$ panelis menyatakan tekstur pellet dengan kategori jelek merupakan persentasi penilaian panelis tertinggi pada kriteria tekstur, dibanding perlakuan yang menggunakan bahan perekat dalam kategori tekstur baik. Hal ini dipengaruhi oleh proses gelatinisasi pada kandungan pati bahan perekat sehingga pellet yang dihasilkan akan kelihatan kompak dan merata, tetapi pada perlakuan tanpa bahan perekat tidak mengalami proses tersebut maka pellet yang dihasilkan tidak menunjukkan kualitas fisik pellet yang baik. Menurut Winarno (2002) menyatakan gelatinisasi adalah perubahan yang terjadi pada granula pati pada waktu mengalami pembengkakan yang luar biasa dan tidak dapat kembali ke bentuk semula. Ketika proses gelatinisasi terjadi maka mampu mempertahankan struktur dan integritas granula pati, sehingga menyebabkan penyerapan pada bahan dan menghasilkan pellet yang lebih kompak.

\section{Ukuran Diameter dan Panjang Pellet Ayam Pedaging Fase Finisher}

Rata-rata ukuran diameter dan panjang hasil pellet ayam pedaging fase finisher dengan penambahan berbagai bahan perekat terlihat pada Tabel 6.

Tabel 5. Pengamatan penambahan berbagai bahan perekat pada proses pelleting terhadap tekstur, warna dan bau pada pellet ayam pedaging fase finisher

\begin{tabular}{lrrrr}
\hline \multirow{2}{*}{ Kriteria } & \multicolumn{4}{c}{ Perlakuan $(\%)$} \\
\cline { 2 - 5 } & P0 & P1 & P3 \\
\hline Tekstur & & & & \\
Amat Baik & 16,67 & 8,33 & 20,00 & 8,33 \\
Baik & 38,33 & 53,33 & 51,67 & 55,00 \\
Jelek & 41,67 & 28,33 & 18,33 & 28,33 \\
Sangat Jelek & 3,33 & 10,00 & 10,00 & 8,33 \\
Warna & & & & \\
Amat Baik & 36,67 & 13,33 & 20,00 & 16,67 \\
Baik & 45,00 & 50,00 & 56,67 & 66,67 \\
Jelek & 18,33 & 36,67 & 23,33 & 16,67 \\
Sangat Jelek & 0,00 & 0,00 & 0,00 & 0,00 \\
Bau & & & & \\
Amat Baik & 40,00 & 30,00 & 31,67 & 18,33 \\
Baik & 51,67 & 68,33 & 55,00 & 71,67 \\
Jelek & 6,67 & 1,67 & 13,33 & 10,00 \\
Sangat Jelek & 1,67 & 0,00 & 0,00 & 0,00 \\
\hline
\end{tabular}

Tabel 6. Rata-rata ukuran diameter dan panjang pellet ayam pedaging fase finisher dengan penambahan berbagai bahan perekat

\begin{tabular}{ccc}
\hline \multirow{2}{*}{ Perlakuan } & \multicolumn{2}{c}{ Parameter } \\
\cline { 2 - 3 } & Ukuran Diameter Pellet $(\mathrm{mm})$ & Ukuran Panjang Pellet $(\mathrm{mm})$ \\
\hline P0 & $4,0 \pm 0,03$ & $6,1 \pm 0,30$ \\
P1 & $4,0 \pm 0,06$ & $6,1 \pm 0,53$ \\
P2 & $3,9 \pm 0,15$ & $6,7 \pm 0,95$ \\
P3 & $3,9 \pm 0,07$ & $7,1 \pm 0,17$ \\
\hline
\end{tabular}


Berdasarkan analisis ragam menunjukkan bahwa penambahan berbagai bahan perekat tidak berpengaruh nyata $(\mathrm{P}>0.05)$ terhadap ukuran diameter dan panjang pellet ayam pedaging fase finisher. Hal ini dikarenakan diameter dan panjang pellet merupakan output dari diameter lubang die dan ukuran pisau pada mesin yang dapat disesuaikan berdasarkan standar ukuran pellet ayam pedaging fase finisher. Sehingga dengan penambahan berbagai bahan perekat yang digunakan tidak memiliki pengaruh terhadap ukuran diameter dan panjang pellet ayam pedaging fase finisher.

Berdasarkan hasil pengukuran diameter dan panjang pellet ayam pedaging fase finisher, terdapat ukuran diameter terendah 3,9 mm, tertinggi $4,0 \mathrm{~mm}$ dengan rata-rata $3,95 \mathrm{~mm}$ dan panjang pellet terendah 6,1 mm, tertinggi 7,1 $\mathrm{mm}$ dengan rata-rata 6,5 mm pada pellet yang dihasilkan. Dengan demikian diameter pada lubang die memiliki ukuran yang sama, begitupun dengan panjang pellet yang dipengaruhi oleh pisau pemotong yang telah diatur pada mesin pellet dengan ukuran yang sama. Sehingga hasil pengukuran yang diperoleh sesuai dengan standard pellet ayam pedaging fase finisher. Sesuai dengan pendapat Retnani (2011), menyatakan bahan baku yang telah mengalami penambahan uap panas dipres menjadi bentuk pellet dengan diameter 3,5-4,0 mm dan panjang 0,5-0,6 $\mathrm{cm}$. Pellet yang keluar dari lubang die akan dipotong oleh pisau pellet.

\section{KESIMPULAN}

Berdasarkan penelitian yang telah dilakukan dapat disimpulkan bahwa rata-rata kinerja teoritis dan kinerja aktual mesin pellet masing-masing $33,62 \mathrm{~kg} / \mathrm{jam}$, dan $29,54 \mathrm{~kg} / \mathrm{jam}$, penyusutan bahan $12,13 \%$, serta efiensi kinerja mesin diatas $87,87 \%$. Uji organoleptik pellet ayam pedaging fase finisher menggunakan berbagai bahan perekat lebih $50 \%$ panelis menilai baik dan $41,67 \%$ panelis menilai jelek pada pellet tanpa bahan perekat.

\section{UCAPAN TERIMA KASIH}

Terima kasih diucapkan kepada Dekan, Ketua Program Studi Peternakan, serta Kepala Laboratorium Teknologi dan Industri Pakan Fakultas Peternakan Universitas Hasanuddin atas segala bantuan dan dukungannya sehingga penelitian ini dapat diselesaikan sebagai bagian dari penelitian penyelesaian tugas akhir.

\section{DAFTAR PUSTAKA}

Adi, R.N, N. Amalia, Suherman, \& Ratnawati. 2013. Penggunaan teknologi pengeringan unggun terfluidisasi untuk meningkatkan efisiensi pengeringan tepung tapioka. Jurnal Teknologi Kimia dan Industri 2(3):37-42.

Krisnan, R. \& S.P. Ginting. 2009. Penggunaan solid ex-decanter sebagai binder pembuatan pakan komplit berbentuk pellet: evaluasi fisik pakan komplit berbentuk pellet. Seminar Nasional Teknologi Peternakan dan Veteriner. Bogor, 13-14 Agustus 2009. Hlm: 480-486.

Nugraha, A. 2017. Analisis kapasitas produksi pada PT. Mount Dreams Indonesia dengan metode rought cut capacity planning (RCCP). JTM 05(1):135-142.

Pujaningsih, R. I. 2006. Pengelolaan Bijian pada Industri Makanan Ternak. Alif Press. Semarang.

Purwantoro, D., T. Dianpratiwi, \& S. Markumningsih. 2018. Analisis penggunaan alat mesin pertanian berbasis traktor tangan pada kegiatan perawatan budidaya tebu. Agritech 38(3):313-318.

Retnani, Y. 2015. Proses Industri Pakan. IPB Press. Bogor.

Retnani, Y. 2011. Proses Produksi Pakan Ternak. Ghalia Indonesia. Bogor.

Retnani, Y., N. Hasanah, Rahmayeni, \& L. Herawati. 2010. Uji sifat fisik ransum ayam broiler bentuk pellet yang ditambahkan perekat onggok melalui proses penyemprotan air. Agripet 11(1):13-18.

Retnani, Y., Y. Harmiyanti, D.A.P. Fibrianti, \& L. Herawati. 2009. Pengaruh penggunaan perekat sintetis terhadap ransum ayam broiler. Agripet 9(1):1-10.

Sari, Y.I., S. Limin, \& Suparmono. 2016. Kajian pengaruh penambahan tepung tapioka sebagai binder dalam pakan buatan terhadap pertumbuhan ikan nila gift (Oreochromis, Sp). e-JRTBP 5(1):537-545

Smith, H.P. \& L.H. Wilkes. 1990. Mesin dan Peralatan Usaha Tani. Terjemahan Tri Purwadi. UGM Press. Yogyakarta.

Standar Nasional Indonesia. 2002. Tata cara penyiapan benda uji dari contoh agregat. Badan Standarisasi Nasional. (SNI 13-67172002). 
Standar Nasional Indonesia. 2015. Pakan ayam ras pedaging (broiler) - Bagian 3: masa akhir (finisher). Badan Standardisasi Nasional. (SNI 8173.3:2015).

Steel R.G.D. \& J.H. Torrie. 1991. Prinsip dan Prosedur Statistika. Terjemahan B. Sumantri. Penerbit PT. Gramedia Pustaka Umum. Jakarta.

Sulistiyanto, B., C.S. Utama, \& S. Sumarsih. 2016. Kualitas fisik-organoleptik pellet limbah penetasan sebagai bahan pakan alternatif pada aras penambahan bentonit yang berbeda. Prosiding Seminar Nasional Peternakan Berkelanjutan 8. Fakultas Peternakan Universitas Padjajaran. Sumedang, 16 November 2016.
Syamsu, J.A. 2007. Karakteristik fisik pakan itik bentuk pellet yang diberi bahan perekat berbeda dan lama penyimpanan yang berbeda. Jurnal Ilmu Ternak 7(2):128-134.

Winarno, F.G. 2002. Kimia Pangan dan Gizi. Gramedia Pustaka Utama. Jakarta.

Yatno. 2011. Fraksinasi dan sifat fisiko-kimia bungkil inti sawit. Jurnal Angrinak 1 (1):1116. 